\title{
Effect of angled spray nozzle designs on spray distribution and droplet spectrum $^{1}$
}

\author{
Efeito de pontas de pulverização de jato angulado sobre a distribuição e espectro de \\ gotas
}

\author{
Matheus Mereb Negrisoli²*, Diego Miranda de Souza ${ }^{3}$, Danilo Morilha Rodrigues ${ }^{4}$, Patrick Julio de Jesus ${ }^{2}$ and \\ Carlos Gilberto Raetano ${ }^{2}$
}

\begin{abstract}
New technologies have been developed to promote uniform, sustainable, safe and effective application of phytosanitary products. In this scenario, spray nozzles of different designs and jet angles can optimize application. Therefore, we aimed to analyze the effect of angled flat fan spray nozzles on spray pattern uniformity and droplet spectrum formation. The spray volumetric distribution of standard flat fan, double flat fan and the new angled flat fan spray nozzle, using two spray volumes were assessed. For that, the spray pattern distribution and the coefficient of variation (CV) were determined. The droplet spectrum characterization produced by the same treatments was performed in a real-time particle size analyzer. Also the effect of adding a fungicide mixture associated with an adjuvant on droplet formation was evaluated. All spray nozzles, regardless of design and spray volumes evaluated, produced CV values below 7\%, considered acceptable by international uniformity standards. There was a difference in spray pattern according to the spray nozzle design and spray volume. It was evidenced that the main differences found in droplet spectrum occurred due to spray nozzle type, spray mixture and nominal flow rate, with little influence of spray jet angled or spray volumes.
\end{abstract}

Key words: Angled flat fan. Uniformity of volumetric distribution. Droplet size. Volume median diameter.

RESUMO - Novas tecnologias têm sido desenvolvidas para promover a aplicação de produtos fitossanitários de modo uniforme, sustentável, seguro e eficaz. Nesse contexto, pontas de pulverização com diferentes desenhos e ângulos do jato podem otimizar a aplicação. Assim, o objetivo foi avaliar o efeito de pontas de jato plano angulado sobre a uniformidade de distribuição da pulverização e formação do espectro de gotas. A distribuição volumétrica da pulverização de pontas de jato plano padrão, jato plano duplo e da nova ponta de jato plano angulado foram avaliadas em duas taxas de aplicação. Para isso, o padrão de distribuição da pulverização e o coeficiente de variação (CV) foram determinados. A caracterização do espectro de gotas nos tratamentos foi conduzida em medidor de tamanho de partículas em tempo real. Também foi avaliado o efeito da adição de mistura fungicida associada a um adjuvante na formação das gotas. Todas as pontas de pulverização, independente do desenho e da taxa de aplicação, produziram valores de $\mathrm{CV}$ abaixo de 7\%, considerados aceitáveis nos padrões internacionais de uniformidade. Houve diferença no padrão de distribuição em função do tipo de ponta de pulverização e taxa de aplicação. Foi evidenciado que as maiores diferenças encontradas no espectro de gotas ocorreram devido ao tipo de ponta de pulverização, mistura de calda e vazão nominal, com pouca influência da angulação do jato ou taxa de aplicação.

Palavras-chave: Jato plano angulado. Uniformidade de distribuição volumétrica. Tamanho de gotas. Diâmetro mediano volumétrico.

DOI: $10.5935 / 1806-6690.20210029$

Editor-in-Chief: Prof, Alek Sandro Dutra - alekdutra@ufc.br

*Author for correspondence

Received for publication on 06/12/2019; approved on 01/05/2021

'Parte da Dissertação do primeiro autor, apresentado ao Programa de Pós-Graduação em Agronomia: Proteção de Plantas - Universidade Estadual Paulista/UNESP - Faculdade de Ciências Agronômicas/FCA

${ }^{2}$ Departamento de Proteção Vegetal, Faculdade de Ciências Agronômicas(FCA), Universidade Estadual Paulista(UNESP), Programa de PósGraduação em Agronomia (Proteção de Plantas), Botucatu-SP, Brasil, matheusmnegrisoli@gmail.com (ORCID ID 0000-0002-1267-1747), patrickjuliodejesus@hotmail.com (ORCID ID 0000-0002-0847-1654), carlos.raetano@unesp.br (ORCID ID 0000-0001-8897-9310)

${ }^{3}$ Curso de Engenharia Agronômica, Faculdades Gammon, Paraguaçu Paulista-SP, Brasil, diego-agronomia@hotmail.com (ORCID ID 0000-0002-4965-713X) ${ }^{4}$ Departamento de Agricultura, Faculdade de Ciências Agronômicas (FCA), Universidade Estadual Paulista(UNESP), Programa de Pós-Graduação em Agronomia (Agricultura), Botucatu-SP, Brasil, danilomrodrigues@outlook.com (ORCID ID 0000-0002-5156-184X) 


\section{INTRODUCTION}

Phytosanitary products are widely used in agriculture through spraying onto several crops. An adequate application is important to ensure proper crop protection against several pests that affect crop production (MATTHEWS; BATEMAN; MILLER, 2016). In most cases, the pesticide application is conducted to maximize pest control efficacy evenly in the field, which can be severely impaired when using unsuitable equipment or spraying setup for each specific situation.

The quality of a spray application is directly influenced by the components of the sprayer (FERGUSON et al., 2015; MASSOLA et al., 2018), application parameters (FORNEY et al., 2017; HASSEN; SIDIK; SHERIFF, 2013) and climate conditions (DE COCK et al., 2017). In this scenario, pesticide application technology plays a key role in determining the best parameters for each situation, which may vary according to the target as well as the pesticide being used (DE COCK et al., 2017; NUYTTENS; ZWERTVAEGHER; DEKEYSER, 2017). One of the most important factors is to achieve a uniform spraying distribution throughout the field at the correct dosage and with minimum product losses due to spray drift (DE COCK et al., 2017; MATUO, 1990).

Spray nozzles are considered the most important component of the sprayer and are responsible for drop generation by breaking a liquid film into droplets of different sizes (MATTHEWS; BATEMAN; MILLER, 2016). Besides, spray nozzles combined several working parameters directly influence spray distribution (FORNEY et al., 2017), affecting target assertiveness and penetration into the crop canopy (CREECH et al., 2018; NEGRISOLI et al., 2019; SHARPE et al., 2017).

Flat fan nozzles are widely used in Brazil with varied chemical classes and crop cultivations (CHECHETTO et al., 2017; RAETANO; MOTA, 2019). Recently, a variation of the flat fan nozzle was developed to improve spray penetration for these crops, presenting a spray jet angled design at 38 degrees relative to the vertical plane. New nozzle designs, such as the angled flat fan as well as the double flat fan have been used to improve the spray coverage and spray deposition on bottom crop canopy (DURÃO; BOLLER, 2017; NEGRISOLI et al., 2019).

As spray nozzle performance at different operational conditions can vary significantly, a general study is necessary to assess the volumetric distribution of spray nozzles under specific conditions as well as the quality and droplet spectrum. This information is valuable to determine the best addressment of new technologies for different crops and applications. Moreover, the evaluation of droplet formation of different nozzles determines uniformity of droplet size, potential risk of drift, and the capacity for the spraying to promote spray coverage in the crop canopy (DE COCK et al., 2017; DORR et al., 2013; FERGUSON et al., 2015). Droplet size directly affects spray coverage and functionality of contact pesticides, as finer droplets have greater capacity to penetrate inner regions and cover a greater surface (FERGUSON; HEWITT; O’DONNELL, 2016).

Therefore, it is necessary to investigate the effect of the angled flat fan on drop formation and spray pattern distribution, thus enabling the use of these results to understand the effect of nozzle design on spraying quality. The hypothesis is that angled flat fan nozzles or duplication of the spray jet do not interfere in spray uniformity distribution or droplet spectrum formation. Thus, we aimed to evaluate the effect of angled flat fan nozzles on spray distribution uniformity and droplet spectrum.

\section{MATERIAL AND METHODS}

To validate the hypothesis, two experimental units were conducted: i) analysis of spray volumetric distribution of different flat fan nozzles; and ii) characterization of droplet spectrum.

\section{Analysis of spray volumetric distribution}

This experiment was conducted using an indoor spray patternator designed to evaluate of spray volumetric pattern distribution (ISO STANDARD 5683-1:1996). The spray patternator was composed of channels spaced at $5.0 \mathrm{~cm}$, containing a $250 \mathrm{~mL}$ tube at the end of each channel, allowing the collection and measurement of the volume collected by the end of the established time. The spray nozzles were set in the spray boom allocated above the patternator.

The analysis of the coefficient of variation (CV) of the spray nozzles' volumetric distribution was conducted in a completely randomized design and the treatments distributed in a $3 \times 2$ factorial scheme, consisting of three types of flat fan spray nozzle and two spray volumes (Table 1), with four replications. The influence of the flat fan nozzle design on the spray pattern distribution and the droplet spectrum was evaluated at two different volumes in order to promote better comparison of the effects of varying spray volumes along with different nozzle designs. The working pressure was adjusted to reach the spray volume desired in a hypothetical situation, similar to field application, with a displacement velocity of $9 \mathrm{~km} \mathrm{~h}^{-1}$ and flow rates of $1.875 \mathrm{~L} \mathrm{~min}^{-1}$ and $0.937 \mathrm{~L} \mathrm{~min}^{-1}$ to the volumes 250 and $125 \mathrm{~L} \mathrm{ha}^{-1}$, respectively. 
Table 1 - Treatments according to the spray nozzle and spray volume with their respective operational conditions

\begin{tabular}{cccccc}
\hline Treatments & Spray jet & Nozzle type & Operating pressure $(\mathrm{kPa})$ & ${\text { Flow rate }\left(\mathrm{L} \mathrm{min}^{-1}\right)}$ Spray volume $\left(\mathrm{L} \mathrm{ha}^{-1}\right)$ \\
\hline 1 & Standard flat fan & AXI 11003 & 189 & 0.937 & 125 \\
2 & Standard flat fan & AXI 11004 & 426 & 1.875 & 250 \\
3 & Double flat fan & JGT 11002 & 384 & 0.937 & 125 \\
4 & Double flat fan & JGT 11003 & 757 & 1.875 & 250 \\
5 & Angled flat fan & DEFY 3D 100025 & 268 & 0.937 & 125 \\
6 & Angled flat fan & DEFY 3D 10004 & 425 & 1.875 & 250 \\
\hline
\end{tabular}

Manufacturer: Nozzles AXI and JGT (JACTO) and DEFY 3D (PENTAIR/HYPRO)

Each nozzle unit was individually tested on the patternator in two spray volumes using the respective working pressure and flow rate described (Table 1). The spray pattern distribution of the treatments was evaluated only with water and the spray nozzles spaced of $0.50 \mathrm{~m}$ apart and the same distance of boom height, simulating the distance from the target in a field application and according to the manufacturer's recommendations for proper overlap.

The spray volume was collected individually in the glass tubes after 60 seconds of spraying, recording the reading of the volume obtained in each tube. The mean volume data collected were used to determine the spray pattern distribution of each treatment. With the distribution patterns of each spray nozzle unit, it was possible to simulate the spray overlap every $0.50 \mathrm{~m}$ from the central nozzle channel right below the spray nozzle tip (BAUER; RAETANO, 2004). Based on the overlapping simulation of the obtained volume in a Microsoft Excel $^{\circledR}$ spread sheet, the $\mathrm{CV}$ for each treatment was calculated using the accumulated volume from the overlapping region.

The calculation of $\mathrm{CV}$ was performed using Microsoft $\mathrm{Excel}^{\circledR}$ and is represented by the equation (E1). Later, analysis of variance and means test was performed.

$$
C V(\%)=\frac{S T D E V(X: Y)}{\operatorname{mean}(x)} * 100
$$

Where: $C V(\%)$ is the percentage of the coefficient of variation; $\operatorname{STDEV}(X: Y)$ is the function for calculating the sample standard deviation; mean (x) is the sample mean.

\section{Characterization of droplet spectrum}

Droplet spectrum was determined by a realtime particle size analyzer, Mastersizer $\mathrm{S}^{\circledR}$ (Malvern Instruments Ltda.), as described by Cunha, Teixeira and Fernandes (2007) and De Bortoli et al. (2012). The droplet population spectrum was recorded directly by the laser beam diffraction method at the moment the sprayed droplets passed through the equipment sampling region (SCHICK, 1997). The light diffraction pattern determines the droplet diameter as the smaller the droplet diameter, the greater the diffraction (SCHICK, 1997). The equipment was calibrated to evaluate droplets of 0.5 to $900 \mu \mathrm{m}$ in diameter, with a $300 \mathrm{~mm}$ lens.

This experiment was conducted in a completely randomized design with six treatments, evaluating the same three types of flat fan nozzles with two spray volumes, using pressure and flow rate as described previously (Table 1). For each type of spray nozzle, three different units in five replications each were evaluated, totaling 15 replications for each treatment. Since the spray mixture used in applications majorly affects the droplet spectrum (FERGUSON et al., 2015; MASSOLA et al., 2018) it was decided to conduct the test with two spray solutions: i) only water; and ii) fungicide tryfloxystrobin (150 $\left.\mathrm{g} \mathrm{L}^{-1}\right)$ associated with prothioconazole $\left(175 \mathrm{~g} \mathrm{~L}^{-1}\right)$ (Fox ${ }^{\circledR}$; dosage: $0.4 \mathrm{~L} \mathrm{ha}^{-1}$ ), suspension concentrate (SC), associated with the soybean oil methyl ester adjuvant (Aureo $^{\circledR} ; 0.3 \% \mathrm{v} \mathrm{v}^{-1}$ ), emulsifiable concentrate (EC), simulating an application for disease control in soybean crop (NEGRISOLI et al., 2019). Spraying was performed by a pressurized compressed air system, adjusting the pressure according to each treatment (Table 1) by a precision regulator.

The laser beam was positioned $400 \mathrm{~mm}$ below the spray nozzle, which was installed on an oscillator so that the entire spray jet passed through the light beam in three seconds. The total time for the droplet size readings was $1.5 \mathrm{~s}$ (half of the spray jet), with one reading every two milliseconds, totaling 750 readings for each spray. The evaluation was conducted in an environment without light during the readings, temperature of $27.5^{\circ} \mathrm{C}$, relative air humidity of $55 \%$ and without wind.

The nozzle holder system was inclined for the Defy 3D evaluations so that the spray jet was parallel to the pickup system without contact and interference with the device lens. Similarly, the double flat fan spray nozzles (JGT) were also inclined and one of the jets isolated, evaluating the droplet spectrum of only one jet in the same vertical direction as the others (DORR et al., 2013). 
The following qualitative spray parameters were analyzed: $\mathrm{DV}_{01}, \mathrm{VMD}\left(\mathrm{DV}_{05}\right), \mathrm{DV}_{09}$, percentage of droplets with a diameter smaller than $100 \mu \mathrm{m}$ (droplets prone to drift) and uniformity coefficient (SPAN). The median volumetric diameter (VMD) is the droplet diameter that represents the volume sprayed in two equal parts; one with droplets larger than the VMD, and another one with droplets smaller than that value, expressed in micrometers $(\mu \mathrm{m})$. The $\mathrm{DV}_{01}$ is the diameter that comprises $10 \%$ of the volume sprayed that has droplets with a diameter less than or equal to its value, while $\mathrm{DV}_{09}$ is the diameter of which $90 \%$ of the sprayed volume has droplets with a diameter less than or equal to its value. From these values, the uniformity coefficient of the droplet spectrum was calculated for the difference between $\mathrm{DV}_{09}$ and $\mathrm{DV}_{01}$ by the VMD (RAETANO; MOTA, 2019; FERGUSON et al., 2015).

\section{Data analysis}

For the spray volumetric distribution, mean values of the percentage of $\mathrm{CV}$ were subjected to analysis of variance (ANOVA) by F-test and the means compared by Tukey's test, both at $5 \%$ probability $(\mathrm{p}<0.05)$. In the droplet spectrum evaluation, means of $\mathrm{DV}_{01}, \mathrm{VMD}, \mathrm{DV}_{09}$, percentage of droplets with a diameter smaller than $100 \mu \mathrm{m}$ and SPAN were also subjected to ANOVA by F-test at $5 \%$ probability and compared separately for each type of spray mixture by Tukey's test $(\mathrm{p}<0.05)$. The statistical analysis was made using SISVAR software ${ }^{\circledR}$ (FERREIRA, 2011).

\section{RESULTS AND DISCUSSION}

\section{Spray volumetric distribution}

All flat fan nozzles (AXI, JGT and Defy 3D), in both spray volumes (125 and $250 \mathrm{~L} \mathrm{ha}^{-1}$ ), presented similar spray pattern distribution, with a peak of volume collected in the central region of the channels right below the tip of the spray nozzle, with a gradual volume reduction towards the channels at the end of both sides of the spray jet (Figure 1).

However, subtly different behavior was observed for the spray nozzles and volumes. In the three spray nozzles evaluated with the lowest flow rate, there was a smaller volume peak collected in the center, presenting a flatter curve (Figure 1). On the other hand, with the highest flow rate of JGT and Defy 3D and both volumes with AXI, sharper peaks in the central region of collection were observed, with a stronger fall towards the extremities.

Therefore, regardless of the spray jet angle, the number of spray jets or absence of angulation, the spray pattern distribution was similar for all nozzles evaluated. An ideal spray distribution is that with the largest deposition in the center, without collection peaks and symmetrical extremities with gradual inclination (FORNEY et al., 2017). Due to this
Figure 1 - Spray pattern distribution of the spray nozzles (A) standard flat fan (AXI 11003 and AXI 11004), (B) double flat fan (JGT 11002 and JGT 11003) and (C) angled flat fan (Defy 3D 100025 and 10004) under respective pressures of 182; 434; 379; 758; 434 and $324 \mathrm{kPa}$ and hypothetical spray volumes of 125 and $250 \mathrm{~L} \mathrm{ha}^{-1}$
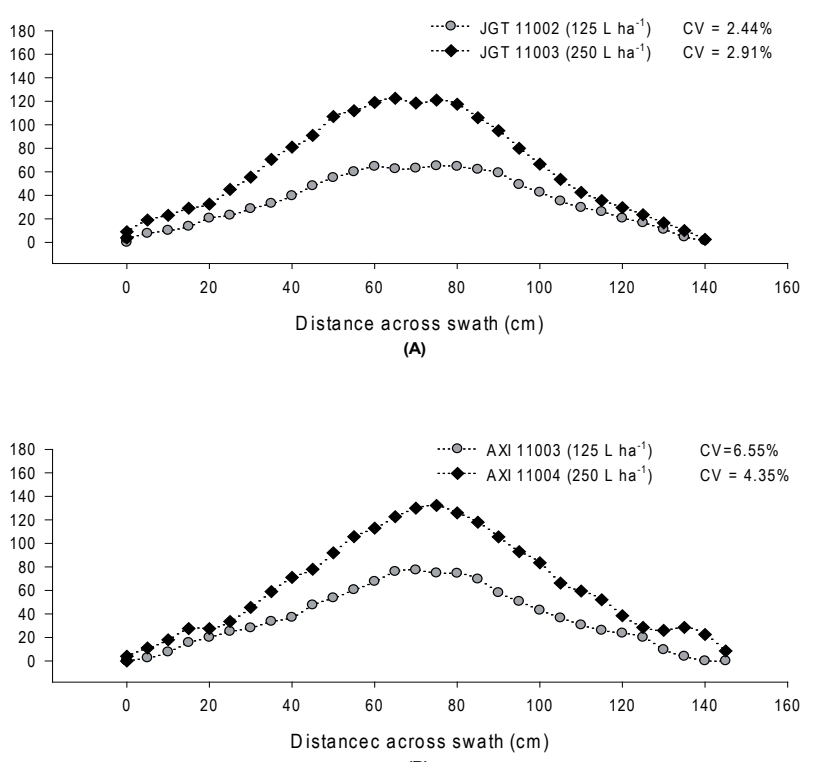

(B)

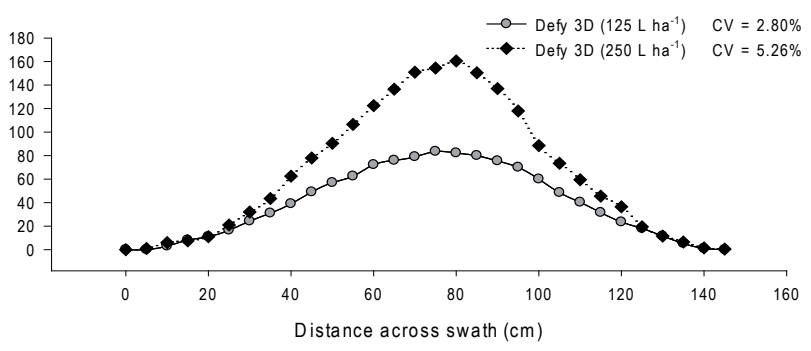

(C)

distribution pattern, spray jet overlapping is necessary to uniform the distribution on the target (MATTHEWS; BATEMAN; MILLER, 2016).

In the $\mathrm{CV}$ calculation of spray volumetric distribution, a significant difference was found for the interaction between spray nozzle and spray volume $(p<0.05)$, demonstrating the influence of both factors on spray distribution uniformity (Table 2). In general, a higher $\mathrm{CV}$ was found for the spray nozzles using the highest flow rate and a spray volume of $250 \mathrm{~L} \mathrm{ha}^{-1}$, except for the standard flat fan nozzle (AXI).

The flat fan (AXI) and angled flat fan nozzles (Defy 3D) showed differences in spray distribution with different spray volumes $(p<0.05)$ (Table 2$)$. The spray nozzle AXI presented a less uniform distribution (higher CV) at $125 \mathrm{~L} \mathrm{ha}^{-1}$, whereas Defy 3D presented 
Table 2 - Coefficient of variation (\%) of the spray pattern volumetric distribution for each spray nozzle and volume evaluated

\begin{tabular}{lcc}
\hline \multirow{2}{*}{ Spray nozzles } & \multicolumn{2}{c}{ Spray volume } \\
\cline { 2 - 3 } & $125 \mathrm{~L} \mathrm{ha}^{-1}$ & $250 \mathrm{~L} \mathrm{ha}^{-1}$ \\
\hline Flat fan (AXI) & $6.55 \mathrm{aA}$ & $4.35 \mathrm{abB}$ \\
Double flat fan (JGT) & $2.44 \mathrm{bA}$ & $2.91 \mathrm{bA}$ \\
Angled flat fan (DEFY 3D) & $2.80 \mathrm{bB}$ & $5.26 \mathrm{aA}$ \\
Cause of variation & F Test & Probability \\
Spray nozzle (N) & 9.44 & $0.0016^{*}$ \\
Spray volume (V) & 0.21 & $0.6657^{\mathrm{NS}}$ \\
$\mathrm{N}$ x V & 6.72 & $0.0060^{*}$ \\
\hline
\end{tabular}

NS: Not significant; * significant at $\mathrm{p}<0.05$ by $\mathrm{F}$ test. Means followed by the same letter in each comparison did not differ by Tukey's test at $5 \%$ probability $(\mathrm{p}<0.05)$. Uppercase letters compare CV (\%) values across spray volumes (lines). Lower case letters compare CV (\%) values across spray nozzles (columns)

a CV significantly smaller at $125 \mathrm{~L} \mathrm{ha}^{-1}$. For both spray volumes, the double flat fan nozzle (JGT) presented the best spray uniform distribution, with $\mathrm{CV}$ values below 3\%. Therefore, in general, there was no intrinsic influence of the design and angle of flat fan nozzles on the spray volumetric distribution uniformity.

Comparing the spray pattern distribution of the treatments (Figure 1) with the CV values (Table 2), it was observed that the higher peak in the central region of the spray distribution (higher quantity of collected volume), the greater the $\mathrm{CV}$ found. On the other hand, the spray pattern distribution at $125 \mathrm{~L} \mathrm{ha}^{-1}$ and at both spray volumes with the JGT nozzle had a notably less sharp curve in this region with the highest spray volume. The volume collection was similar over a greater distance in the central region of the spraying, corresponding to a lower $\mathrm{CV}$ and greater uniformity of distribution.

Similarly, Cunha and Ruas (2006) reported adequate spray distribution uniformity of double flat fan nozzles with air induction, highlighting the spray boom height and working pressure as the main factors that influence the $\mathrm{CV}$ and uniformity of spray distribution. In this study, the lowest $\mathrm{CV}$ values were found using a boom height/spray nozzle spacing ratio similar to that used in our research, conducted at a $0.50 \mathrm{~m}$ spacing between spray nozzles at the same distance of boom height from the target (1:1 ratio).

Forney et al. (2017), demonstrated that slight inclination of the spray nozzle in relation to the spray boom, as well as boom height and working pressure may also significantly affect spray distribution uniformity, regardless of the spray nozzle type. In this research, depending on the pressure used, the CV ranged from $4 \%$ to $18 \%$ when the spray nozzle was angled from $0^{\circ}$ (vertical) to $8^{\circ}$. However, studies analyzing the effect of spray jet angles by the spray nozzle design itself have not been found. Moreover, for the angled flat fan and double flat fan, the nozzle was already designed to spray in inclined positions, which probably explains the little or no influence of the type of nozzle on the spray distribution found by Forney et al. (2017) with angled nozzles.

Based on the results found, all the spray nozzles evaluated, regardless of the spray volume, maintained $\mathrm{CV}$ values below $7 \%$ and therefore, are considered acceptable by international standards (EUROPEAN COMMITTEE FOR STANDARDIZATION, 1997). Considering that spray volumetric distribution uniformity was evaluated according to the theorical operational parameters for spraying in the field, it can be inferred that the treatments used are capable of promoting an adequate and uniform spray distribution. However, this condition comes from a theorical point of view, since other factors such as climate and field ground (variation in boom height and nozzle spacing/boom height ratio) may significantly affect the uniformity of spray distribution in the field (FORNEY et al., 2017; MASSOLA et al., 2018).

\section{Droplet spectrum analysis}

The values obtained for volumetric diameters, SPAN and drift potential are very important to characterize the spraying technology, providing a better qualitative characterization of the spray for technical comparisons. Based on the manufacturer's information, the spray nozzles evaluated in this experiment with their nominal flow rate and working pressure, produce medium-sized droplets, with a VMD between 236 and $340 \mu \mathrm{m}$ (AMERICAN SOCIETY OF AGRICULTURAL AND BIOLOGICAL ENGINEERING, 2009).

The VMD values using only water ranged from 190 to $300 \mu \mathrm{m}$ (Table 3). Therefore, under those conditions, the double flat fan and angled flat fan nozzles, at both flow rates, produced droplets of medium size, while the flat fan 
nozzle produced fine sized droplets (smaller than $236 \mu \mathrm{m}$ ). However, a slight increase in the VMD was found when adding the fungicide mixture associated with the adjuvant, regardless of nozzle type and flow rate, producing medium droplets with values between 257 and $320 \mu \mathrm{m}$ (Table 4).

Spraying with only water, a significant difference was found between both spray nozzle types and nominal flow rate of similar nozzle types (Table 3). The double flat fan nozzles produced the largest droplet sizes, followed by angled flat fan and, lastly, standard flat fan. For the hypothetical volumes of 125 and $250 \mathrm{~L} \mathrm{ha}^{-}$ 1, a larger VMD was found for nozzles with increasing flow rate, except the Defy $3 \mathrm{D}$ nozzle. Following the same trend, higher $\mathrm{DV}_{01}$ and $\mathrm{DV}_{09}$ were found in the droplets produced by the double flat fan nozzle (JGT) (Table 2). Nevertheless, as for VMD, smaller droplet diameters were observed in the AXI nozzle at the highest nominal flow rate.

Similarly, there was an even more significant increase in VMD in the treatments with fungicide and adjuvant mixtures (soybean oil methyl ester). Considering the spray nozzles, the double flat fan (JGT) showed the highest VMD, followed by the Defy 3D and AXI nozzles (Table 4). Once again, a higher VMD was observed when increasing the nominal flow rate of the nozzles. After adding fungicide and adjuvant to the spray solution, there was an inversion in the $\mathrm{DV}_{01}$ values in relation to the nominal flow rate of each nozzle, in which all the nozzles with the lowest flow rate obtained a significantly larger diameter. For $\mathrm{DV}_{09}$ results, the same pattern was found as spraying with only water (Table 3), with higher values for double flat fan nozzles and higher flow rates (Table 4).

Table 3 - Characterization of droplet spectrum as a percentage of accumulated volume, percentage of droplets prone to drift and relative amplitude (SPAN) produced by flat fan spray nozzles at different spray volumes, spraying only water

\begin{tabular}{lcccccc}
\hline Spray jet & $\mathrm{DV}_{0,1} \mu \mathrm{m}$ & $\mathrm{DV}_{0.5} \mu \mathrm{m}$ & $\mathrm{DV}_{0.9} \mu \mathrm{m}$ & $<100 \mu \mathrm{m} \%$ & \multicolumn{1}{c}{ SPAN } & Droplet size $^{1}$ \\
\hline Flat fan (AXI 11003) & $90 \mathrm{~b}$ & $190 \mathrm{~d}$ & $354 \mathrm{~d}$ & $13.48 \mathrm{~b}$ & $1.39 \mathrm{c}$ & Fine \\
Flat fan (AXI 11004) & $75 \mathrm{~d}$ & $195 \mathrm{~d}$ & $388 \mathrm{c}$ & $17.73 \mathrm{a}$ & $1.60 \mathrm{~b}$ & Fine \\
Angled fat fan (Defy 3D 100025) & $93 \mathrm{~b}$ & $254 \mathrm{c}$ & $553 \mathrm{~b}$ & $11.70 \mathrm{c}$ & $1.81 \mathrm{a}$ & Medium \\
Angled flat fan (Defy 3D 10004 & $83 \mathrm{c}$ & $251 \mathrm{c}$ & $540 \mathrm{~b}$ & $14.14 \mathrm{~b}$ & $1.82 \mathrm{a}$ & Medium \\
Double flat fan (JGT 11002) & $106 \mathrm{a}$ & $275 \mathrm{~b}$ & $559 \mathrm{ab}$ & $8.75 \mathrm{~d}$ & $1.65 \mathrm{~b}$ & Medium \\
Double flat fan (JGT 11003) & $103 \mathrm{a}$ & $300 \mathrm{a}$ & $582 \mathrm{a}$ & $9.51 \mathrm{~d}$ & $1.60 \mathrm{~b}$ & Medium \\
\hline F test & $83,35^{*}$ & $206,6^{*}$ & $200,2 *$ & $81,8^{*}$ & $40,3 *$ & \\
CV (\%) & 5,49 & 4,81 & 5,43 & 11,27 & 5,95 &
\end{tabular}

"significant at $\mathrm{p}<0.05$ by $\mathrm{F}$ test. Means followed by the same letter did not differ by Tukey's test $(\mathrm{p}<0.01) .{ }^{1}$ Classification based on ASAE droplets size classification in function of $\mathrm{DV}_{0.5^{\circ}}$. (Fine: $106-235 \mu \mathrm{m}$; Medium: $236-340 \mu \mathrm{m}$ )

Table 4 - Characterization of droplet spectrum as a percentage of accumulated volume, percentage of droplets prone to drift and relative amplitude (SPAN), produced by flat fan spray nozzles at different spray volumes, spraying with fungicide mixture (tryfloxystrobin + prothioconazole) associated to ester soybean oil methyl ester adjuvant

\begin{tabular}{lcccccc}
\hline Spray jet & $\mathrm{DV}_{0.1} \mu \mathrm{m}$ & $\mathrm{DV}_{0.5} \mu \mathrm{m}$ & $\mathrm{DV}_{0.9} \mu \mathrm{m}$ & $<100 \mu \mathrm{m} \%$ & SPAN & Droplet size $^{1}$ \\
\hline Flat fan (AXI 11003) & $91 \mathrm{ab}$ & $257 \mathrm{~d}$ & $512 \mathrm{~d}$ & $11.54 \mathrm{ab}$ & $1.64 \mathrm{~b}$ & Medium \\
Flat fan (AXI 11004) & $59 \mathrm{~d}$ & $259 \mathrm{~d}$ & $541 \mathrm{~cd}$ & $18.85 \mathrm{a}$ & $1.87 \mathrm{a}$ & Medium \\
Angled fat fan (Defy 3D 100025) & $102 \mathrm{~b}$ & $291 \mathrm{c}$ & $570 \mathrm{ab}$ & $9.64 \mathrm{c}$ & $1.61 \mathrm{~b}$ & Medium \\
Angled flat fan (Defy 3D 10004 & $87 \mathrm{c}$ & $298 \mathrm{bc}$ & $576 \mathrm{a}$ & $12.21 \mathrm{~b}$ & $1.65 \mathrm{~b}$ & Medium \\
Double flat fan (JGT 11002) & $121 \mathrm{a}$ & $308 \mathrm{ab}$ & $543 \mathrm{bc}$ & $7.14 \mathrm{~d}$ & $1.38 \mathrm{~d}$ & Medium \\
Double flat fan (JGT 11003) & $101 \mathrm{~b}$ & $319 \mathrm{a}$ & $580 \mathrm{a}$ & $9.85 \mathrm{c}$ & $1.50 \mathrm{c}$ & Medium \\
\hline F test & $57,6^{*}$ & $28,5^{*}$ & $13,8^{*}$ & $57,0^{*}$ & $39,3^{*}$ & \\
CV (\%) & 11,16 & 6,52 & 4,99 & 17,38 & 6,17 & \\
\hline
\end{tabular}

"significant at $\mathrm{p}<0.05$ by $\mathrm{F}$ test. Means followed by the same letter did not differ by Tukey's test ( $<<0.01) .{ }^{1}$ Classification based on ASAE droplets size classification in function of $\mathrm{DV}_{0.5}$. (Medium: $\left.236-340 \mu \mathrm{m}\right)$ 
The larger droplet size produced by the double flat fan nozzles (JGT) can be explained by the air induction technology in the nozzle, which acts by inserting air into the droplets and increasing their size significantly (DORR et al., 2017). Spray nozzles with air induction influence the dynamics of droplet formation which, in turn, can influence spray deposition on the target (NUYTTENS et al., 2007). Besides, it is known that conventional nozzles produce smaller droplets with higher initial velocity, which is directly correlated with the VMD of the droplets and working pressure (DORR et al., 2017).

Considering the effect of the flow rate of similar types of nozzles on droplet formation, Cunha, Teixeira and Fernandes (2007) also found significantly larger values of droplet size with an increase in nominal flow rate. According to the authors, the size of the nozzle outlet orifice influences the fractionation of the liquid into droplets, with the larger the orifice, the smaller the fractionation and therefore, the larger the droplet size.

The use of adjuvants in the spray mixture can significantly interfere with droplet size (GRIESANG et al., 2017; MOTA; ANTUNIASSI, 2013). In these studies, an increase in droplet size was reported when using vegetable oil in comparison with surfactants, mineral oil and using just water. The VMD increased from 250 to approximately $320 \mu \mathrm{m}$ (MOTA; ANTUNIASSI, 2013). Alternatively, the use of phosphatidylcholine and propionic acid surfactants interfered heterogeneously in the droplet size according to the spray nozzle evaluated, reducing VMD values of standard flat fan nozzles while there was a slight increase in size using hollow cone nozzles (GRIESANG et al., 2017).

It is worth mentioning the importance of the correct selection of droplet size for certain biological targets. For disease management in soybean crops, especially soybean rust (Phakopsora pachyrhizi), it is recommended to spray droplets with a VMD between 250-300 $\mu \mathrm{m}$ (CUNHA; JULIATTI; REIS, 2014). Thus, De Bortoli et al. (2012) reported a higher percentage of disease severity in treatments with a coarse droplet spectrum. According to these authors, spraying with very fine and fine droplets promoted higher deposition in comparison with the use of larger droplets. Besides, a significantly lower VMD of the droplets present in the lower region of plant was observed due to the higher canopy penetration capacity.

For the correct spray characterization, the homogeneity of droplet sizes produced (SPAN) should also be considered along with the VMD. According to Cunha, Teixeira and Fernandes (2007), the bigger the SPAN, the greater the amplitude of droplet size found, whereas values tending to zero are considered less heterogenous. Based on the results found, all the treatments presented heterogenous SPAN regarding the flat fan nozzles, spray volume and mixture, ranging from 1.38 to 1.87 (Tables 3 and 4).
When spraying only water, greater droplet spectrum homogeneity (lower SPAN) was observed with AXI nozzles at the lowest flow rate, followed by the same nozzle at a higher flow rate and both JGT nozzles (Table 3). Conversely, by adding the fungicide and adjuvant to the spray solution greater homogeneity of droplet spectrum with JGT nozzles for both flow rates was observed followed by the Defy 3D and AXI nozzles (Table 4). At the same flow rate, there was a reduction in the relative amplitude value by adding the fungicide and adjuvant to the spray solution to angled flat fan and double flat fan nozzles.

Another important factor that may influence droplet size is the climate conditions at the time of spraying. Low relative humidity (lower than 50\%), high temperature (higher than $30^{\circ} \mathrm{C}$ ) and high wind speed (higher than $8.5 \mathrm{~km} \mathrm{~h}^{-1}$ ) increase the loss of smaller droplets at the time of spraying (RAETANO; MOTA, 2019). For that matter, the values of droplets smaller than $100 \mu \mathrm{m}$ are of great importance in understanding of the potential risk of spray drift. The lower this value, the lower the risk of spray drift, with values below $15 \%$ considered the safest for spraying (CUNHA; TEIXEIRA; FERNANDES, 2007).

Some of the values found are not considered safe for spray drift risk (Tables 3 and 4). For both water and fungicide mixture with adjuvant, the increase in flow rate interfered heterogeneously in the percentage of droplets smaller than $100 \mu \mathrm{m}$. Using only water in the spraying, the AXI 11004 nozzle produced more than $15 \%$ of droplets smaller than $100 \mu \mathrm{m}$ (Table 3 ). This result is consistent with the diameter values found $\left(\mathrm{DV}_{0,1}, \mathrm{DV}_{0,5}\right.$ and $\left.\mathrm{DV}_{0,9}\right)$, from which the smallest values in comparison to other treatments were found and therefore, producing droplets more prone to drift.

On the other hand, except for the JGT 11003 and AXI 11004 nozzles, there was a reduction in the percentage of droplets smaller than $100 \mu \mathrm{m}$ when the fungicide mixture associated with the adjuvant was added to the spray mixture (Table 4). Only AXI 11004 presented values above the recommended (18.85\%).

The reduction in the percentage of droplets smaller than $100 \mu \mathrm{m}$ by adding a vegetable oil to the spray mixture found here is dissimilar to other findings (MOTA; ANTUNIASSI, 2013) where a significant increase in the percentage of droplets smaller than $100 \mu \mathrm{m}$ by the addition of a vegetable oil were reported. This contrast in values may be due to the spray nozzle used and due to chemical differences of the adjuvants evaluated, which may vary up to $20 \%$ in the concentration of emulsifier, besides being a methylated vegetable oil with different properties (RAETANO; CHECHETTO, 2019). The interaction between the nozzle design with different adjuvants on the droplet spectrum needs further study, especially when it comes to oily adjuvants. 
The double flat fan nozzles were the ones that produced a percentage of droplets smaller than $100 \mu \mathrm{m}$ significantly lower than the others, with values below $10 \%$ regardless of flow rate and spray mixture (Tables 3 and 4). These values can be explained by the presence of air induction, whose technology aims to reduce drift specifically by increasing droplet size (FERGUSON et al., 2015). The reduction on the percentage of droplets smaller than $100 \mu \mathrm{m}$ of Defy 3D nozzles was more influenced than the other treatments after the addition of fungicide and adjuvant, with a reduction of $21 \%$ and $15 \%$ for the flow rates of 0.93 and $1.87 \mathrm{~L} \mathrm{~min}^{-1}$, respectively (Tables 3 and 4).

Therefore, in general, it was demonstrated that major differences found in the droplet spectrum occurred in function of the type of spray nozzle, spray mixture and flow rate, with little influence regarding the spray jet angles of flat fan nozzles or spray volumes used. Knowledge of the spray pattern distribution and the characterization of the droplets produced by new spray nozzles or spraying setups is important, since it determines the best addressment of new technologies for specific situations in the phytosanitary management (DORR et al., 2013; FERGUSON et al., 2015). Consequently, it is still necessary to obtain better understanding of the influence of angled flat fan nozzles on spray deposition of field crops, which has been shown to interfere with the deposition characteristics and spray coverage aspects (FOQUÉ; NUYTTENS, 2011; NEGRISOLI et al., 2019).

\section{CONCLUSIONS}

1. The spray nozzles AXI, JGT and Defy $3 \mathrm{D}$, regardless of the flow rate, angle of the spray jet and operational conditions showed adequate spray distribution uniformity with a coefficient of variation below $7 \%$. The spray pattern distribution of the nozzles and spray volumes influenced the coefficient of variation;

2. Spray jet angle and nozzle design did not interfere with the production of spray droplets even under different spray volumes;

3. The fungicide mixture tryfloxystrobin plus prothioconazole associated with the soybean oil methyl ester adjuvant interfered unevenly in the droplet spectrum of the treatments, increasing VMD and reducing the potential risk of spray drift.

\section{ACKNOWLEDGEMENTS}

This study was financed in part by Coordenação de Aperfeiçoamento de Pessoal de Nível Superior - Brasil (CAPES), Finance Code 001.

\section{REFERENCES}

AMERICAN SOCIETY OF AGRICULTURAL AND BIOLOGICAL ENGINEERING. ASABE S572. Spray nozzle classification by droplet spectra. St. Joseph, 2009. 8 p.

BAUER, F.; RAETANO, C. G. Perfis de distribuição volumétrica de pontas XR11003 e TXVK-4 em diferentes condições de pulverização. Engenharia Agrícola, v. 24, n. 2, p. 364-373, 2004.

CHECHETTO, R. G. et al. Caracterização da taxa de aplicação e pontas de pulverização utilizadas no estado do Mato Grosso. Magistra, v. 26, n. 1, p. 89-97, 2014.

CREECH, C. F. et al. Herbicide spray penetration into corn and soybean canopies using air-induction nozzles and a drift control adjuvant. Weed Technology, v. 32, n. 1, p. 72-79, 2018.

CUNHA, J. P. A. R.; JULIATTI, F. C.; REIS, E. F. Tecnologia de aplicação de fungicida no controle da ferrugem asiática da soja: resultados de oito anos de estudos em minas gerais e goiás. Bioscience Journal, v. 30, n. 4, p. 950-957, 2014.

CUNHA, J. P. A. R.; RUAS, R. A. A. Uniformidade de distribuição volumétrica de pontas de pulverização de jato plano duplo com indução de ar. Pesquisa Agropecuária Tropical, v. 36, n. 1, p. 61-66, 2006.

CUNHA, J. P. A. R.; TEIXEIRA, M. M.; FERNANDES, H. C. Avaliação do espectro de gotas de pontas de pulverização hidráulicas utilizando a técnica da difração do raio laser. Engenharia Agrícola, v. 27, p. 10-15, 2007.

DE BORTOLI, M. P. et al. Espectro de gotas de pulverização e controle da ferrugem-asiática-da-soja em cultivares com diferentes arquiteturas de planta. Pesquisa Agropecuária Brasileira, v. 47, n. 7, p. 920-927, 2012.

DE COCK, N. et al. Investigation on optimal spray properties for ground based agricultural applications using deposition and retention models. Biosystems Engineering, v. 162, p. 99-111, 2017.

DORR, G. J. et al. A comparison of initial spray characteristics produced by agricultural nozzles. Crop Protection, v. 53, p. 109-117, 2013

DURÃO, C. F.; BOLLER, W. Spray nozzles performance in fungicides applications for Asian soybean rust control. Engenharia Agrícola, v. 37, n. 4, p. 709-716, 2017.

EUROPEAN COMMITTEE FOR STANDARDIZATION. EN 12761-2. Agricultural and forestry machinery: sprayers and liquid fertilizer distributors. Brussels: CEN, 1997. 17 p.

FERGUSON, J. C. et al. Determining the uniformity and consistency of droplet size across spray drift reducing nozzles in a wind tunnel. Crop Protection, v. 76, p. 1-6, 2015.

FERGUSON, J. C.; HEWITT, A. J.; O'DONNELL, C. C. Pressure, droplet size classification, and nozzle arrangement effects on coverage and droplet number density using airinclusion dual fan nozzles for pesticide applications. Crop Protection, v. 89, n. 1, p. 231-238, 2016.

FERREIRA, D. Sisvar: a computer statistical analysis system. Ciência e Agrotecnologia, v. 35, n. 6, p. 1039-1042, 2011. 
FOQUÉ, D.; NUYTTENS, D. Effects of nozzle type and spray angle on spray deposition in ivy pot plants. Pest Management Science, v. 67, n. 2, p. 199-208, 2011.

FORNEY, S. H. et al. Laboratory and full boom-based investigation of nozzle setup error effects on flow, pressure, and spray pattern distribution. Applied Engineering in Agriculture, v. 33, n. $5,2017$.

GRIESANG, F. et al. How much do adjuvant and nozzles models reduce the spraying drift in agricultural spraying. American Journal of Plant Sciences, v. 8, n. 11, p. 2785-2794, 2017.

HASSEN, N. S.; SIDIK, N. A. C.; SHERIFF, J. M. Effect of nozzle type, angle and pressure on spray volumetric distribution of broadcasting and banding application. Journal of Mechanical Engineering Research, v. 5, n. 4, p. 76-81, 2013.

MASSOLA, M. P. et al. Spray volume distribution pattern and droplet size spectrum from ceramic nozzles. Revista Brasileira de Engenharia Agrícola e Ambiental, v. 22, n. 11, p. 804-809, 2018.

MATTHEWS, G. A.; BATEMAN, R.; MILLER, P. Métodos de aplicação de defensivos agrícolas. 4. ed. São Paulo: Andrei Editora, 2016. 623 p.

MATUO, T. Técnicas de aplicação de defensivos agrícolas. Jaboticabal: FUNEP, 1990. 139 p.

MOTA, A. A. B.; ANTUNIASSI, U. R. Influência de adjuvantes no espectro de gotas de ponta com indução de ar. Energia na Agricultura, v. 28, n. 1, p. 1-5, 2013.
NEGRISOLI, M. M. et al. Performance of new flat fan nozzle design in spray deposition, penetration and control of soybean rust. European Journal of Plant Pathology, v. 155, n. 3, p. 755-767, 2019.

NUYTTENS, D. et al. Effect of nozzle type, size and pressure on spray droplet characteristics. Biosystems Engineering, v. 97, n. 3, p. 333-345, 2007.

NUYTTENS, D.; ZWERTVAEGHER, I. K.; DEKEYSER, D. Spray drift assessment of different application techniques using a drift test bench and comparison with other assessment methods. Biosystems Engineering, v. 154, p. 14-24, 2017.

RAETANO, C. G.; CHECHETTO, R. G. Adjuvantes e formulações. In: ANTUNIASSI, U. R.; BOLLER, W. Tecnologia de aplicação para culturas anuais. 2. ed. Passo Fundo: Aldeia Norte, 2019. p. 29-48.

RAETANO, C. G.; MOTA, A. A. B. Pontas de pulverização hidráulicas. In: ANTUNIASSI, U. R.; BOLLER, W. Tecnologia de aplicação para culturas anuais. 2. ed. Passo Fundo: Aldeia Norte, 2019. p. 67-89.

SCHICK, R. J. An engineer's practical guide drop size. Wheaton: Spraying Systems, 1997. 28 p.

SHARPE, S. M. et al. Spray penetration into a strawberry canopy as affected by canopy structure, nozzle type, and application volume. Weed Technology, v. 32, n. 1, p. 80-84, 2017. 